\title{
FACTORS AFFECTING ETHICS AND ANTI-CORRUPTION COMMISSION ON PERFORMANCE OF PROCUREMENT PERSONNEL IN TRANS-NZOIA COUNTY, KENYA
}

\author{
Bryan Atemba Mbati and Dr. Anthony Osoro
}

Jomo Kenyatta University of Agriculture and Technology,Kenya

\begin{abstract}
This study focused at the area of ethics and anti-corruption commission on performance of procurement personnel in Trans-Nzoia County, Kenya, the specific objectives were; integrity of staff, transparency and accountability, information and Communication technology and government policies respectively. The researcher used descriptive research design for this study. The target population was 150 respondents. The researcher did a census survey, where purposive sampling techniques was used. Since the respondents were with similar experience, exposure and skills. The research instruments were pilot tested first for reliability and validity, where $10 \%$ of the respondents were issued with the questionnaires before the actual collection of data and analysis and presentation.
\end{abstract}

Keywords: integrity of staff, transparency and accountability, information and Communication technology and government policies on performance of procurement personnel

\subsection{Introduction:}

According to Anti-Corruption and Economic Crimes Act of Banerjee et al.(2019), corruption means an offence that involves bribery, fraud, embezzlement or misappropriation of public funds, abuse of office, breach of trust; or an offence involving dishonesty- in connection with any tax, rate levied under any Act; or under any written law relating to the elections of persons to public office (The Anti-Corruption and Economic Crimes Act Beaman, and Magruder (2012).Professional ethics is about managing relations which is a crucial part in SCM. Successful companies use supply chains not only to reduce cost and complement the product but also to nurture long-term value added associations. A wide range of stakeholders are interested in the social, ethical and environmental performance of the government's supply chain. Globally corruption has had an effect on many different bodies and institutions two of the major bodies affected by corruption are the Government and its Public Institutions. In the long run, no country can afford the social, political or economic costs that corruption entails. It erodes public confidence in political institutions and leads to contempt for the rule of law; it distorts the allocation of resources and undermines competition in the market place; it has a devastating effect on investment, growth and development .In Europe corruption remains a major challenge to democracy and the rule of law .According to the widely used Worldwide Governance Indicators and Quality of Government EU Regional Data survey Hungary ranks as one of Central and Eastern Europe's most corrupt countries (Beaman, BenYishay, Magruder \& Mobarak, 2015).

There is strong consensus among researchers and practitioners regarding the strategic importance of developing efficient purchasing techniques to increase transparency and fairness, reduce corruption, ensure competitiveness and reduce costs. An increasing number of government and non-government authorities are adopting ethics and anti-corruption commission solutions to reap the above stated benefits. In a greatly competitive business environment, organizations are required to manage their supply chains adequately to ensure efficiency in operations (Beaman et al., 2012). Companies need to adequately link their operations with their supply chain partners such as suppliers distributors, wholesalers, retailers and end customers so as to improving the performance of the organization Supply Chain Administration (SCM) refers to the integration of key business development from end 
use through original suppliers that provide products, services, and information that adds value for customer and other stakeholders. The vision of the supply chain as a holistic construct with close cooperation between the different organizational units has replaced the traditional picture of it as a collection of vertically organized purposely units (Banerjee, Chandrasekhar, Duflo \& Jackson, 2019).

\subsection{Statement of the Problem}

In spite of the reforms carried out in Public Procurement in Kenya, the performance of procurement personnel have not fully achieved the objectives of integrity of staff, transparency and accountability, information and communication technology and government policies. Public procurement related malpractices were estimated to have cost the country over Kshs.700 billion State organizations are under greater scrutiny on Factors affecting Ethics and Anti-Corruption on performance of procurement personnel, not just the input and output but the whole operation in terms of transparency and accountability, ICT adoption, and integrity (Irungu, 2010). However this research project observed the need to adopt approaches for better procurement performance and the need for supply chains to be rapid, adaptable and aligned. There was need to do a study in the Kenyan context so as to validate its findings before coming up with a general consensus (Osoro et al., 2015). The factors affecting Ethics and Anti-Corruption Commission on performance of procurement personnel has insufficiently been addressed, with a documentation of no association most parastals and government organizations procurement development are difficult to enforce as integrity is lacking (Mbae, 2014). This has left an evident knowledge gap, which the study intends to bridge by determining the Factors affecting Ethics and Anti-corruption Commission on performance of procurement personnel using integrity of staff, transparency and accountability, information and communication technology and government policies (Muange, 2013).Therefore there in need to do a study in the Kenyan context so as to bridge the existing gap using the new knowledge.

1.3 Integrity of Staff: Ethics often brings several stakeholders in the global supply chain together, creating informal institutional structures through which a dialogue can be established. This dialogue, and the mutual trust that it helps create, stands in contrast to the adversarial associations that often existed previously (Telewa, 2014). Breaking down these barriers can bring several benefits because regulatory systems based on trust and dialogue seems to outperform those based on confrontation (Solomon \& Ayebale, 2017). Flows of information and knowledge can be improved, thus reducing costs, because far more data is shared in situations of trust (Abdul-Rahamon \&Adejare, 2014). Trust also enables the system to be more flexible it can learn and adapt more readily than system based on more formal organizational boundaries, and it can draw on resources whenever they reside within the system . Ethical issues concerning producers are key considerations in the supply chain Administration. Service providers are confronted with a plethora of ethical subjects such as child labor, fair working conditions, fair wages, the ecological sustainability of their production methods, intellectual property right violations and counterfeits, to name just a few (Schmidt, 2017). However, despite the unethical, unjustifiable and degrading nature of child labor the problem is exacerbated when sub-contractors involve children in provision of goods or services to the company (Solomon \& Ayebale, 2017).

1.3.1 Transparency and Accountability: Professional codes of conduct generally are written in broad conceptual terms rather than in specific situational or descriptive terms. They leave room for interpretation and often may seem ambiguous (Solomon \& Ayebale, 2017). 
Procurement professionals cannot abide merely by the letter of the law or the specific words in any code, but rather, they are guided by the spirit of the law or the broader concept that the code is intended to express. Organizations and professions often seek to address standards of conduct through the adoption of codes of conduct. According to , one reason why many procuring organizations avoid detailed and specific codes is these may give the impression that anything not prohibited is permitted or that anything not specifically addressed is not important (Simiyu, 2016). People in other professions who have not been trained in or are not appreciative of procurement ethics may not realize that a situation not specifically identified in the code may still be vitally important (Simiyu, 2016). Those who do not understand the foundation of a general requirement may not be able to apply a code in a specific situation. Therefor accountability comes in play for those procurement professionals who understand the code of ethics. No matter how hard policy-makers try, they would never specify in law, code, regulation, rule, or other written requirement everything that a procurement officer needs to know regarding what is allowed or appropriate and what is prohibited or shunned (Schmidt, 2017). It is necessary for procurement officers to understand what the law or rule is intended to accomplish. The United Nations Oath of Office clearly expresses the UN's values, principles, rules and regulations and how procurement officers should regulate their conduct and perform their duties within the interests of the UN. The respective FRR guiding the procurement process of the UN organizations also address several ethical values such as fairness, integrity, transparency and equal treatment Purchasing and supply Administration professionals should encourage colleagues to declare any material personal interest which may affect, or be seen to affect, their impartiality or judgment in respect of their duties (Shiferaw, 2015).

1.3.2 Information and Communication Technology: In the recent past, Government organizations have increasingly come to realize that public agencies must utilize Information and Communication Technology, to enhance procurement development in public sectors (Schmidt, 2017). The use of ICT is a key component, governments have to utilize it during development process of stimulating the economy, lowering existing digital gaps, modernizing public sector and improving government performance as it is evidence by use of IFMIS.ICT helps in reducing opportunities and incentives for fraud and improves the quality of Government agencies procurement Administration, including monitoring and decision making, thus encouraging private industries in the public market participate competitively (Shiferaw, 2015). From a business perspective, implementing scalable communication infrastructures such as wide area networks, accommodating various types of Government Agencies requires a day to day basis that has a provision of broad band internet access, online services, internal collaboration, and Administrative data handling (Alatas, Banerjee, Chandrasekhar, Hanna \& Olken , 2016). Information and communication technology on the performance of procurement personnel towards the Trans nzoia County in Kenya (Schmidt, 2017). The disadvantaged groups use ICT purposes provided by computer hardware and software on equal basis with others. Generally, increase of availability to easy accessibility of ICT, a positive step has been done, removing barriers preventing people with disabilities from participating equally in society. The use of public procurement to further social goals is still very much attached on ICT accessibility \& implementation. Ways of ICT accessibility criteria are applied to the purchase of ICT especially by National governments. Procurement system " Buy accessible wizard" enables ICT purchases by federal government authorities to be tracked and checked. This category of ICT is mostly applicable in USA and Japan; where Japan market has been flooded by this product (Shiferaw, 2015). 
1.3.3 Government Policies: Kenya's General Penal Code (GPC) criminalizes the act of giving and receiving a bribe, abuse of office, trading influence, and fraud. Individuals and companies are criminally liable, and bribery between business Kenyan and foreign public officials is forbidden. The Penal Code fails to adequately criminalize bribery of officials in foreign state-owned entities, and the obligation of officials to report foreign bribery is not clear. The GPC does not differentiate between bribes and facilitations payments (Schmidt, 2017. The legality of gifts and hospitality depend on intent and benefit obtained, and if the act has led to an undue advantage or improper influence of a person's decision making. A company can be held criminally liable and fined for corruption offences committed by persons acting on the company's behalf (Shiferaw, 2015). Other legal anti-corruption regulations consist of codes of conduct for government staff and ministers to regulate conflicts of interest. Those affected by illegal activities are required to report them. The adequateness of corruption prevention by the national government is considered to vary by locality, and the level of transparency varies in proportion to administrative capacity. Kenya's Criminal Code prohibits active and passive bribery, embezzlement, fraud, abuse of office, breach of trust, and abuse of insider information. It criminalizes bribery between businesses, of Kenyan and foreign public officials, and through intermediaries such as Ethics and Anti-Corruption Commission (Schmidt, 2017).

1.3.4 Performance of Procurement Personnel in Trans Nzoia County: Measuring the performance of supply chains has become vital for all organizations involved in disaster Administration This is particularly due to increasing competition in the sector for scarce resources and increasingly great demands from the public to improve visibility and accountability (Mwangi, 2014). Competitive bidding is a transparent process that invites all potential suppliers to a bid but may not be applied in the cases of great emergency procurement of aid due to time limitation. Secondly is reputation, which means the evaluation of a firm by its stakeholders in terms of their effect, esteem and knowledge. Unethical procurement practices in supply networks endanger the credibility of organizations. For instance, offer of gifts by contractors with a motive of giving bribes results in negative publicity which adversely affects the procurement achievement. Another objective is accountability which identifies who is responsible for the actions within the procurement process and how well the actions are performed (Owuoth \& Mwangangi, 2015). Government ecosystem is made up of many different groups with different incentives and levels of commitment like the international community, made up of large and small aid agencies. To improve on accountability, conflict of interest aims at ensuring that assigning responsibility is not compromised on the basis of professional association with partners. Improved response time is another objective procurement performance; improved response time translates into speed and accuracy in delivering aid to the affected areas (Owuoth \& Mwangangi, 2015). A successful procurement performance mitigates the urgent needs of a population with a sustainable reduction of their openness in the shortest amount of time. For example, ethical negotiation enables organizations combine purchasing requirements over a certain period of time (Lambert and Stock, 1993). In addition, ethical reciprocity enables the supplier and buyer obtain a great understanding of mutual problems thus increasing goodwill, whereas unethical reciprocity enables buyers use buying decisions to unsuitability enhance a sales opportunity (Schmidt, 2017). 


\subsection{Research Design}

According to Kothari (2011), a research design is a set of methods and procedures used in collecting and analyzing of variables in this study. A descriptive research design was selected because it provides an accurate way of how qualitative and quantitative research design was combined to support each other. They researcher used numerical and words in explain the phenomena under this study. This design was chosen to meet the objectives of the study which was to determine the knowledge and views of to Tabachnick and Fidell (2013) they observed that descriptive best placed to investigate in depth a phenomenon that requires an exhaustive approach. Factors affecting Ethics and Commission On performance of procurement personnel in Kenya needed such an approach and this research design was therefore considered appropriate for the study. Target population according to Kothari (2011) refers to the entire group of individuals or objects to which a researcher is interested in generalizing the conclusions. The study was conducted in Trans-Nzoia County in Kenya. The target population for this study was 150 employees from the following departments: procurement, accounts and finance, maintenance, Nursing and orthopedic departments respectively.

The multiple regression model was used as follows;

$Y=\beta_{0}+\beta_{1 \times 1}+\beta_{2 \times 2}+\beta_{3 \times 3}+\beta_{4 \times 4}+\varepsilon$ Where;

$Y=$ Performance of procurement personnel in Trans Nzoia County.

$\beta_{0}=$ Constants

$\beta_{1}-\beta_{4}=$ Co-efficient of the Ethics and Ant-Corruption Commission

$\mathrm{X}_{1}=$ Integrity of Staff.

$\mathrm{X}_{2}=$ Accountability and Transparency.

$\mathrm{X}_{3}=$ Information and Communication Technology

$\mathrm{X} 4=$ Government Policies

$\varepsilon=$ error term

\subsubsection{Reliability Test}

A pilot test to 15 respondents was conducted in Trans Nzoia County. The pilot study aimed at ensuring reliability through pretesting and subsequently predetermining whether the instruments could provide reliable data during the main study, as well as check clarity of the instruments to the respondents. Alpha values greater than $0.9(\alpha \geq 0.9$ is Excellent) can be considered excellent, $\alpha \geq 0.7$ but $<0.9$, considered good, $\alpha \geq 0.6$ but $\alpha<0.7$ considered acceptable, $\alpha \geq 0.5$ but $<0.6$ considered poor, while alpha values less than $0.5(\alpha<0.5)$ are considered unacceptable. This is in line with the findings of Kothari (2011). The study benchmarked its reliability test against these alpha values for all the variables under this study. This is in line with the finding of Mutua (2010. The results are presented in the table 2.1 below:

Table 2.1: Reliability Test

\begin{tabular}{lll}
\hline Reliability Statistics & Response & Cronbach's Alpha \\
\hline Integrity of Staff & 15 & 0.792
\end{tabular}


Transparency and Accountability

Government Policies

ICT

Performance of Personnel
15

0.765

15

0.814

15

0.807

0.741

\subsection{Regression Analysis}

To establish the degree of influence of integrity of personnel and performance of procurement personnel in Trans Nzoia County a regression analysis was conducted, with the assumption that: variables are normally distributed to avoid distortion of associations and significance tests, which was achieved as outliers were not identified; a linear relationship between the independent variables and dependent variable for accuracy of estimation, which was achieved as the standardized coefficients were used in interpretation. This is in line with the findings of Muange (2013). The multiple regression model was as follows:

$Y=\alpha+\beta_{1} X_{1}+\beta_{2} X_{2}+\beta_{3} X 3+\varepsilon$

Policy and procedures in public entity $=\alpha+\beta_{1}$ (Integrity of Staff) $+\beta_{2}$ (Transparency and Accountability $)+\beta_{3}$ (Government policies) $+\beta_{4}$ (ICT) + error term.

Regression analysis produced the coefficient of determination and analysis of variance (ANOVA). Analysis of variance was done to show whether there is a significant mean difference between dependent and independent variables. The ANOVA was conducted at $95 \%$ confidence level.

\subsection{Model Goodness of Fit}

Regression analysis was used to establish the strengths of relationship between the integrity of staff and performance of procurement personnel in Trans Nzoia County (dependent variable) and the predicting variables; integrity of staff, transparency and accountability, government policies and information and communication technology (independent variables). The results showed a correlation value $(\mathrm{R})$ of 0.754 which depicts that there is a good linear dependence between the independent and dependent variables. This finding is in line with the findings of Njoroge (2013).

This is in line with the findings of Nyongesa (2014), who observed that this also depicted the significance of the regression analysis done at $95 \%$ confidence level. This implies that the regression model is significant and can thus be used to evaluate the association between the dependent and independent variables. This is in line with the findings of Acharya, Almeida and Campello (2013) who observed that analysis of variance statistics examines the differences between group means and their associated procedures.

Table 2.3 Model Goodness of Fit

\begin{tabular}{llll}
\hline $\mathbf{R}$ & $\mathbf{R}^{2}$ & Adjusted R & Std. Error of the Estimate
\end{tabular}



0.734
0.724
0.756
0.056

a. Predictors: (Constants), integrity of Staff, transparency and accountability, government policy and ICT

b. Dependent Variable: performance of procurement personnel

With an R-squared of 0.724 , the model shows that integrity of staff, transparency and accountability, government policies, and ICT $72.4 \%$ of the variations on performance of procurement personnel in Trans Nzoia County while $27.6 \%$ is explained by other indicators which are not inclusive in study or model. A measure of goodness of fit synopses the discrepancy between observed values and the values anticipated under the model in question. This finding is in line with the findings (Abdul-Rahamon \& Adejare, 2014).

\subsection{Analysis of Variance (ANOVA)}

From the results in table 2.4, analysis of variance statistics was conducted to determine the differences in the means of the dependent and independent variables to show whether a relationship exists between the two. The P-value of 0.005 implies that on performance of procurement personnel in Trans Nzoia County have a significant relationship with Staff competency, compliance strategy, management style, and ICT which is significant at $5 \%$ level of significance. This finding is in line with the findings Oluoch (2015).

Table 2.4

ANOVA Analysis

\begin{tabular}{lccccc} 
& Sum of Squares & df & Mean Square & F & Sig. \\
\hline Regression & 5.157 & 1 & 1.059 & .431 & .002 \\
Residual & 5.463 & 100 & .494 & & \\
Total & $\mathbf{1 0 . 6 1 0}$ & $\mathbf{1 0 1}$ & & & \\
\hline
\end{tabular}

\subsection{Regression Coefficients of Determination}

To determine the relationship between the independent variables and the dependent variable and the respective strengths, the regression analysis produced coefficients of determination. Findings in table 4.16 reveal a positive relationship between the implementation of procurement policies and procedures in public entities in Kenya, king the regression model:

$\mathrm{Y}=\alpha+\beta_{1} \mathrm{X}_{1}+\beta_{2} \mathrm{X}_{2}+\beta_{3} \mathrm{X}_{3}+\beta_{4} \mathrm{X}_{4}+\varepsilon ;$ where,

$\mathrm{Y}=$ Public Entities

$\alpha=$ Constant; $\beta_{1}-\beta_{4}=$ Beta coefficients; $X_{1}=$ integrity of staff; $X_{2}=$ transparency and accountability; $X_{3}=$ government policies; $X_{4}=$ Information and communication technology 
and $\varepsilon=$ Error term, from the result shown below, it's clear that when all the independent variables are regressed against the dependent variable the constant gives a negative result meaning there is a strong relationship and how each predictor has an effect on the dependent variable.

\section{Recommendations}

The study recommends and confirms that the on performance of procurement personnel in Trans Nzoia County was significant in enhancing policies and procedures in Trans Nzoia County in Kenya. That in future different counties needs to strengthen public-private partnerships policy and procedures in the procurement process to all counties in Kenya, so as integrity of staff, transparency and accountability, modern government policy and information and communication technology to be line with the on performance of procurement personnel in Trans Nzoia County. This study therefore sought to explore what past scholars had said on the influence of public -private partnership in on performance of procurement personnel in Trans Nzoia County and tested viability of best on performance of procurement personnel in Trans Nzoia County in Kenya. That from the foregoing, this study recommends that the best on performance of procurement personnel in Trans Nzoia County should strive to be proactive on how to perform better to retain integrity and improve integrity of staff, transparency and accountability, government policies and information and communication technology in Trans Nzoia county. The study has now bridged the existing gap with the creation of new knowledge.

\section{Reference}

1. Abdul-Rahamon, O. A., \&Adejare, A. T. (2014). The Analysis of the impact of

2. Accounting Records Keeping on the Performance of the Small Scale Enterprises. International Journal of Academic Research in Business and Social Sciences, 4(1), 1-17.

3. Acharya, V. V., Almeida, H., \&Campello, M. (2013). Aggregate Risk

4. and the Choice between Cash and Lines of Credit. The Journal of Finance, 68(5), 20592116.

5. Alushula.P. (2017). The standard: How Kenyan Banks are reorganizing after the rate capping. Retrieved fromhttps://www.standardmedia.co.ke/business/article/2001253640/abolishing-morning-tea-alook-at-how-banks-are-reorganizing-after-rate-cap

6. Alatas, V., A. Banerjee, A. G. Chandrasekhar, R. Hanna, and B. A. Olken (2016). Network Structure and theAggregation of Information: Theory and Evidence from Indonesia.American Economic Review 106(7),1663-1704.

7. Banerjee, A., A. G. Chandrasekhar, E. Duflo, and M. O. Jackson (2013). The Diffusion of Microfinance.Science 341, 1236498.

8. Banerjee, A., A. G. Chandrasekhar, E. Duflo, and M. O. Jackson (2019). Using Gossips to Spread Information:Theory and Evidence from two Randomized Controlled Trials.Review of Economic Studies. forthcoming..

9. Beaman, L., A. BenYishay, J. Magruder, and A. M. Mobarak (2015). Can network theorybased targetingincrease technology adoption? Mime.

10. Beaman, L. and J. Magruder (2012). Who gets the job referral? Evidence from a social networks experiment.American Economic Review 102(7), 3574-3593.

11. Benhabib, J., A. Bisin, and M. O. Jackson (Eds.) (2010).The Handbook of Social Economics., M. (2010). The Relationship between Organizational Learning and Performance of Christian Health Association of Kenya Hospitals. International Journal for Management Science and Technology, 2(3), 25-37.

12. Health, J. \& Norman, W. (2004).Stakeholders theory, corporate governance and public management. Journal of Business Ethics, 53, $247-265$. 
13. Kothari,C.R (2011). Research Methodology. Methods and Techniques. New

14. Mbae, L. (2014). Public Procurement Law and Procurement Performance of County Government in Kenya; Case of Machakos County Government. International Journal of Research in Management, Economics and Commerce, 2(2), 14-19.

15. Muange, E. (2013). Procurement Legislation and Performance of Constituency Fund Committees in Kenya. International Journal of Science and Research, 2(3), 19-22.

16. Mutua, O. (2010). Public Procurement Practices: Policy Implications and Service Delivery in Selected Ministries Headquarters in Nairobi County, Kenya. Interdisciplinary Journal of Contemporary Research in Business, 2(1), 17-22.

17. Mwangi, M. (2014). The Impact of Public Procurement Policy on Teaching and Learning in Selected Public Secondary Schools in Kahuro District, Murang'a County, Kenya. Interdisciplinary Journal of Contemporary Research in Business, 2(3), 25-36.

18. Njoroge, K. (2012). Effects of Public Procurement Procedures on Financial Performance of Farmers' Cooperative Societies in Kiambu County. International Review of Management and Business Research, 2(3), 24-30.

19. Njoroge, N. (2013). Pharmacy services in post devolution Kenya. Journal of Modern African Studies, 2(3), 29-36. Nyangau, J. (2013). Public engagement and the success of strategy implementation at the ministry of devolution and planning in Kenya. Journal of Modern African Studies, 2(2), 29-34.

20. Nyongesa, L. (2014). Head Teacher's Leadership Style on School Academic Performance in Kenyan Secondary Schools. International Journal of Business and Social Sciences, 2(3), 12 19.

21. Osoro, A., Muturi, W.M.,\&Ngugi, P.K.,(2015),Economic Data Analysis Affecting Performance of Supply Chain Systems in the Petroleum Industries in Kenya.The International Journal of Business \& Management,3(9),98.

22. Oluoch, S.A. (2015). Effects of Technology Adoption on the Procurement Process at Kenya Maritime Authority Mombasa. The International Journal of Business \& Management 3(10)

23. Owuoth, G. G. \&Mwangangi, P.(2015). Effect of public procurement regulations on procurement performance in public sector in Kenya: a case of rural electrification authority. International Journal of Social Sciences Management and Entrepreneurship 2(1):171-184

24. Schmidt, A., (2017). Public Procurement Law and Reform in Developing Countries: International Best Practices and Lessons Learned: Namibia as a Case Study. Nomos.

25. Shiferaw, B., (2015). Assessment Of The Existing Purchasing Policy And Practices And Its Effect On Performance: The Case of Ethiopian Airlines (Doctoral dissertation, St. Mary's University).

26. Simiyu, K. P. I., (2016). Factors Affecting Procurement of Goods In Government Ministries Case Of the National Treasury. Strategic Journal of Business \& Change Management, 3(2).

27. Solomon, P. N., \& Ayebale, D., (2017). Planning Competence and Staff Performance in Muni University, Uganda. European Journal of Management and Marketing Studies.

28. Tabachnick, B. G., \&Fidell, L. S. (2013). Using Multivariate Statistics, $6^{\text {th }}$ ed. Boston: Allyn and Bacon.

29. Telewa, S. (2014).Sustainable Procurement Practices in the Public Water Sector Institutions in Kenya. Journal of Management and Business Studies, 2(3), 19-25. 